Marc L. Greenberg

\title{
Antemurale innovationis: Clausal complementation in the Slovene Mura River (Prekmurje) dialect and its Balkan parallels
}

\begin{abstract}
The paper discusses the opposition between two complementizers/subordinators, $d a$ vs. $k a$, in Prekmurje Slovene. The forms were used up through the first half of the 20th century to distinguish between irrealis $(\mathrm{da})$ and realis $(\mathrm{ka})$ propositions. In the discussion the available evidence is examined in order to establish more precisely the conditions for the distribution of the two forms. In addition, the diachrony and diatopy of the forms are considered in both South Slavic and broader Slavic contexts.
\end{abstract}

Keywords: complementizers, conjunctions, peripheral conservatism, Freising Folia, infinitive loss, irrealis/realis, epistemic modality, reanalysis, subordinators, supine

\section{Preliminaries}

As has been pointed out in the organizing materials for the workshop that led to the present volume, the South Slavic languages provide exemplary material for understanding the diversity in structures of clause combining, not only because of the striking internal dialect differentiation and standardization of several related varieties of Slavic, but also because of the range of language-contact situations encountered in this region. To this one might add also the fact that South Slavic represents speech varieties that descend from Common Slavic due to migration, dating from the sixth century CE, a time when the relatively uniform language began to differentiate into significantly divergent forms, including syntactic reorganization. In this respect, our understanding of the pathways to development are much clearer in phonology and morphology than in syntax (see Greenberg 2017: 521). Notably, the system of clause combining through participial constructions, including the dative absolute, as well as constructions with infinitives and supines, yielded to analytical means of clause combining and subordination in which daughter dialects selected inherited morphological material (verbal

Marc L. Greenberg, University of Kansas, Dept. of Slavic \& Eurasian Languages \& Literatures, 1445 Jayhawk Blvd., Rm. 2080, Lawrence, KS 66045-7594, USA, e-mail: mlg@ku.edu 
morphology, pronominal forms, particles, etc.) and repurposed it, while the older system of participial subordination was retained in circumscribed systems in the grammars of individual languages and dialects (see Andersen 1970; Ambrazas 1990; Friedman and Joseph 2019).

\subsection{Broader implications}

The title of the present paper begins with a reference to issues that were raised in earlier papers by this author leading to this one (Greenberg 2011, 2019). Those papers discussed a distinction in subordinators in the Prekmurje dialect of Slovene distinguishing between what were referred to as "realis" $k a$ and "irrealis" $d a$, where the latter is the cognate form to the generalized subordinator $d a$ found in both standard Slovene and the Bosnian/Croatian/Montenegrin/Serbian (BCMS) standards. The Prekmurje distinction had hitherto gone unnoticed in the scholarly literature on the dialect. The earlier papers noted the surprising parallel between this distinction in Prekmurje and in core Balkan Sprachbund languages (Modern Greek, Albanian, Macedonian, Bulgarian, Balkan Romani, Romanian) vs. its absence in BCMS and the remainder of Slovene and asked whether the contrast may have been a common Prekmurje-Balkan innovation, despite the geographical discontinuity between Prekmurje Slovene, which lies at the northern periphery of the South Slavic area, and the Balkans in south-eastern Europe (Greenberg 2011, 2018; see also Amman and van der Auwera: 300-301 and Mitkovska and Bužarovska, this volume). There are at least some reasons to think this might be the case, as the Prekmurje dialect (including its literary and standard varieties) is in many respects an anomalous dialect of Slovene (Greenberg 2013). It is distinct from the neighboring Kajkavian Croatian dialect, and it has been noted to have similar innovations as those in geographically non-contiguous speech varieties further to the east (Ivić 1958: 30 with respect to BCMS; Schallert and Greenberg 2007 with respect to Bulgarian). In terms of location, we might have expected Prekmurje to pattern with the erstwhile "Pannonian" Slavic space, where we find, for example, common dialect innovations (dating to the 11th c and earlier) crossing from the northern tier of South Slavic (Slovene, Kajkavian Croatian) into West Slavic, notably Slovak (see Krajčovič 1974: 142-149, 314-318; Greenberg 2000: 40-41). Were it to be the case that the Prekmurje dialect agreed in significant ways with the Balkan developments and failed to fit into the geographical contiguity with the generally conservative neighboring Slovene and Croatian Kajkavian dialects, this would overturn the traditional conceptualization of the way that South Slavic dialects pattern. The earlier papers concluded that the Prekmurje contrast is an internal innovation, though they did not elaborate the processes as fully as will be undertaken in the present paper. 


\subsection{The special position of Prekmurje}

The other reference (antemurale) acknowledges the fact that Prekmurje was incorporated into the Hungarian feudal structures following the Hungarian "land-taking" (honfoglalás) in the tenth century, and consequently the communication paths between groups of Slavic speakers in this region with and in the German March who were to become the future Slovenes gradually broke down. With the rise of Turkish incursions in the 16-17th cc. the Prekmurje region itself became cordon sanitaire toward the south, with relics of fortifications still extant, hence the region's Hungarian name Örség 'defense territory' (Župančič 2009: 17). This historical circumstance gives us a general external framework to hypothesize why the Prekmurje dialect diverges from its neighbors.

\subsection{Organization of the paper}

As in the other papers in this volume, the present paper employs as a heuristic tool the template framework outlined in Wiemer (this volume) and the acronyms adopted therein. ${ }^{1}$ In the following exposition I shall address the topic and its subthemes as follows: Section 2 will deal with the theoretical, diachronic, and diatopic considerations of the problem, that is, placing the rough semantic distinction $d a$ (irrealis) vs. $k a$ (realis) in a framework in order to tease out the conditions that determined the choice of each of the complementizers/subordinators (2.1). Sections 2.2-2.7 place the problem in a historical-comparative and diatopic perspective, taking into consideration the origins of the forms (going back to Proto-Indo-European), their semantic development, and the distribution of their configurations in South Slavic languages and dialects. Section 3 focuses on the distribution and attestation of the phenomenon in Prekmurje Slovene. This section is divided into two parts: 3.1 covers the attested period from the 18th century to the first half of the 20th century, when the distinction was still in effect; section 3.2 covers the second half of the 20th century, where the distinction has collapsed in favor of a general complementizer/subordinator $k a$, though some relic uses persist. In section 4 the analysis is synthesized and discussed.

1 I am grateful for advice and grammaticality judgments regarding BCMS from colleagues Siniša Habijanec, Mate Kapović, Anita Peti-Stantić, Nikola Predolac, and Julijana Vučo. I have also received helpful advice from Victor Friedman and Marko Snoj as well as the editors of the volume, Barbara Sonnenhauser and Björn Wiemer. The usual disclaimers apply. 


\section{Theoretical, diachronic, and diatopic considerations}

\subsection{Earlier observations on the ka: da contrast}

The contrast under focus in this paper is the Prekmurje Slovene opposition described in Avgust Pavel's (ostensibly normative, albeit de facto quite descriptive) Prekmurje Slovene Grammar (Pavel 1942; see also Greenberg 2013), where he notes that the conjunction $k a$ is favored in dependent clauses where the proposition is asserted as factual (his terms: Hung valódi, PrSl resznicsen 'true') and $d a$ is favored in clauses that present potential actions or events (Hung. teljesülhetö, mogôcsen 'possible') (§ 446). The contrast had been observed earlier, e.g., by Kühar, who glosses $k a$ as Germ 'daß', Sl 'ker' and $d a$ as Germ 'wenn' (Kühar 1911: 48). Accordingly, in (1) the preference for $k a$ is conditioned by the verb 'said, asserted' in the CTP, while in (2) $d a$ is preferred because of the future-oriented perfective aspect, marking a potential state, of the verb in the dependent clause (DC). (The orthography follows Hungarian pronunciation rules.)

(1) Pravo mi je ka(da) mi zavszema zavüpa. He.said to.me AUX-PR.3SG CoMP to.me fully trusts 'He told me that he completely trusts me.' (Pavel $1942 \S 436$ )

(2) Zavêszt, $\boldsymbol{d a}(\boldsymbol{k a})$ szkoro ozdraví ga je neszkoncsno awareness COMP soon recovers.PFv.3SG him AUX endlessly razveszelíla.

pleased

'The notion that he would soon recover pleased him to no end.' (Pavel 1942§437)

\subsection{Further examination of the ka: da contrast}

The formal opposition at stake here between two complementizers would tempt the structuralist to assume a binary opposition - whether equipollent or privative - between two corresponding semantic primes, which could be roughly categorized as "realis" $(k a)$ and "irrealis" $(d a)$, though we hasten to acknowledge the pitfall of recognizing (ir)reality a priori as a category, as pointed out in Bybee's oftcited article (Bybee 1998). The dynamic nature of the opposition, whether viewed synchronically (e.g., in Pavel 1942, 2013, as illustrated in the examples [1, 2], above) or diachronically (historical examples in the exposition below), suggests 
that the underlying cognitive notions may yield to finer internal distinctions, e.g., speaker's commitment to a potential state of affairs (SoA) as real vs. irreal, or even the emotional state of the speaker. As we shall see, the Prekmurje situation takes the inherited subordinating conjunction $d a$ ("irrealis") and opposes it to the conjunction $k a$ ("realis"), where the latter is extended into the domain of the former, eventually eliminating the distinction by the end of the 20th century. In the exposition we will attempt to sketch the indicators that point to the shape of the cognitive map by referring to the co-occurrence of tense-aspect-mood (TAM) in the complement-taking predicate (CTP) and dependent-clause predicate DC with the variability in complementizers, using, as appropriate, both traditional grammatical terms (indicative, etc.) and abstract notions. As a basic descriptive framework for analyzing the finer-grained analysis of the conditions for $d a$ vs. $k a$, we use as a point of departure the discussion of epistemic modality in Chung and Timberlake 1985: 242-244. In this work, though the focus is on epistemic modality as signaled in the morphology of verbs in various languages, the notional framework used applies in our case both to the indexicality of the complementizer/ subordinator as well as the categories expressed in the verb in the CTP and the DC. Epistemic mode refers to the "actuality of an event in terms of alternative possible situations, or worlds" while restricting "the notion of alternative worlds to those that the speaker considers to be in some sense reasonably close to the actual world" (1985: 242).

\subsection{South Slavic context}

In contrast to the Balkan Slavic languages, the Prekmurje dialect (just as Slovene and neighboring Kajkavian Croatian) lacks special verbal forms for evidentiality (the opposition between witnessed and non-witnessed situations, a separate morphosemantic problem from the epistemic mode, discussed just above, which is of concern here), as well as (along with northern Slavic languages) absolute vs. coordinated past tense. Following the division of the South Slavic languages into western (Slovene, BCMS) and eastern (Bulgarian, Macedonian) subzones, the generalization of the $d a$-complementizer as a subordinating conjunction and complementizer is thought to have been widespread in Western South Slavic, if only one possibility for marking subordination, by the end of the tenth century in the (Latin-rite) Freising Folia for both realis and irrealis propositions, as is the case for standard Slovene and BCMS. In the eastern subzone, canonical OCS largely reserved $d a$ for non-factual propositions both in independent and dependent clauses (Lunt 2001: 161; Večerka 2006: 227), though in some instances the DC could also have been factual (Vaillant 1977: 226). 


\subsubsection{Balkan Slavic parallels}

The distinction in epistemic modality between complementizers $k a$ : $d a$ in Prekmurje Slovene is reminiscent of a similar phenomenon in Balkan Slavic (and nonSlavic) languages, e.g., the Bulgarian contrast betwen če and $d a$ in such examples as in (3) and (4) (examples from Leafgren n.d.: 43).

(3) Na sedem godini za părvi păt otkrix, če On seven years for first time discover.AOR.1sG COMP.FACT 'At seven years old I discovered for the first time

Djado Mraz e izmislen ot vzzrastnite. Santa Claus CoP.3sg made.up.PAST.PASS.MASC.sg by adults.DEF.PL that Santa Claus is made up by adults.'

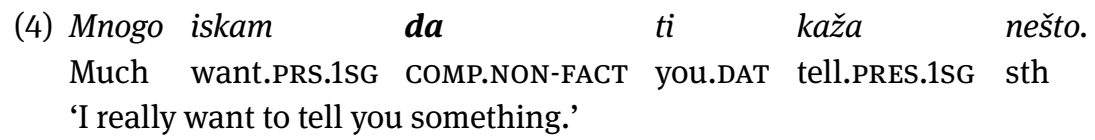

The evidence suggests that the epistemic mode of potential, unrealized events or actions in the DC, marked by $d a$, are the common point of departure for both the Prekmurje and Balkan Slavic contrasts, whether or not the oppositions of the type $k a: d a:: \check{c} e$ : $d a$ were common to all of South Slavic at some earlier time. Otherwise, Slovene stands in contrast to the Balkan Slavic languages and central Slovene dialects share at least the first, albeit minimal, stage of infinitive loss (i.e., development of a short infinitive in -regreet, in contrast to the full infinitive in -ti found in Prekmurje Slovene, detected already in central and southern Slovene dialects by the 16th c., Ramovš 1952: 149-150), which is otherwise most fully developed in the core Balkan Slavic languages, Macedonian and Bulgarian, a precursor to the spread of $d a$-clauses (moreover, such a contrast is found in disparate languages of the world, on which see Nordström 2010: 166ff). With regard to features other than $k a: d a$, the Prekmurje dialect is more conservative than both Balkan Slavic and central Slovene in that it has fully preserved the segmental and accentual properties that distinguish the infinitive and the supine. Both standard and Prekmurje Slovene (as well as, for that matter, Kajkavian Croatian) use the infinitive and supine in circumstances where Balkan Slavic languages would (today) allow the substitution of $d a+$ finite-verb constructions. Overall, Prekmurje Slovene has more possibilities for clause combining, including the use of present and past active participles that had been lost in central Slovene by the nineteenth century. It is therefore at least plausible that the $k a: d a$ contrast is an 
archaism in Prekmurje Slovene, just as other features that set this area off from the rest of Slovene and varieties of BCMS.

The Prekmurje dialect shares with Slovene and other South Slavic languages the inherited modality signaled by $d a$ at the beginning of a clause. What has innovated in Prekmurje Slovene is the development of a new, default complementizer/subordinator $k a$, absent in other varieties of Slovene (nor is it found in Kajkavian Croatian), which has developed in opposition to inherited modal $d a$. This opposition arose some time before the early 18th century and most likely several centuries before it, as we find variation signaling the weakening of the modal opposition already in the earlier texts and, by the time the twentieth century arrives, the opposition is already in decline, captured in the normative grammar of Prekmurje Slovene written in 1942, but is no longer extant in the speech of native speakers raised after the Second World War.

\subsection{Diachronic development of $d a$ complementizer}

The (provisional) contrast between realis and irrealis elaborated for Prekmurje Slovene, where modal $d a$ is the marked member of the opposition is not unexpected in its Slavic context. In OCS the particle $d a$ in earlier attested Slavic introduces clauses indicating intention, potential, hypothetical and possible propositions, as in example (5):

(5) bbdite $i$ molite sę $d a$ ne vbnidete $v ъ$ napastb you.watch and you.pray REFL COMP NEG you.enter into temptation 'Watch and pray lest you enter into temptation.'

(Matt. 26:41, various OCS mss.)

Diachronically, the modal $d a$ comes from a lative particle originating in a demon-

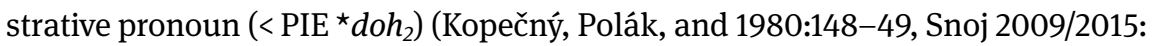
s.v.), though other explanations as to its origin have been proposed (see also Grkovic-Major, this volume). It is generally assumed that in BCMS and Slovene $d a$ spread from potential to indicative propositions as its modal semantics weakened (Grickat 1975:73-78). It is thought that the spread progressed from west to east, a process that Grickat terms a "Balkanism in regression" (Grickat 1975:74), presumably on the basis of the attestations of this usage in the early 11th-century Freising Folia, as in example (6). 
(6)

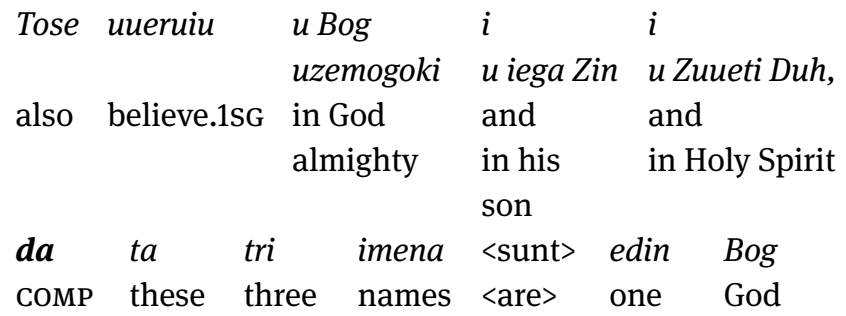

'I also believe in God almighty and his Son and in the Holy Ghost that these three names are one God...'

(FF III)

\subsection{Diachronic development of $k a$ complementizer}

The conjunction/complementizer $k a$ originates in a lative or instrumental pronominal form IE ${ }^{\star} k^{w} e h_{2}$, cognate with Latin $q u \bar{a}$ 'in what manner?, by what means?, whereby?, how?' (Sihler 1995: 268, Snoj 1996: 190-91; Perseus 4.0). These senses are still reflected in the the semantic range of Prekmurje pronominal $k a$, which can express causality, as in $(7 \mathrm{a}, \mathrm{b})$.

(7) a. Nej je mogo priti, ka je

NEG AUX.3SG can.PST.PTCP come.INF COMP AUX.3SG

üšo.

fell PST.PTCP

'He could not come, because it was raining.'

b. Zato je prišo, $k a \quad b i \quad d u g$

Therefor AUX.3sg come.PST.PC COMP COND debt

vöplačo

pay.PST.PTCP

'He came in order that he could pay (his) debt.'

Mukič 2005, s.v. kå

The form is attested with various semantic developments, as in Polish dialectal (8a) and Bulgarian (8b) examples, as reported in (Kopečný 1980: 325). These illustrate the archaic lative meaning and the change from the spatial metaphor to a mental-map metaphor, respectively. 
(8) a. Ka ta idziesz.

whither thither go.pres.2sg

'Where are you going?'

b. Ka smo to čuli, taka go kazvame.

What AUX.3sG that. heard.PL so it.ACc.sG tell.PRS.3sG

'What we have heard, thus we tell it.'

The element $k a$-is also presumed to be the basis for the formation of the Slovene and Kajkavian pronoun $k a j$ 'what' < $k a$-jb (Snoj 1996). The relic form $k o$, glossed as 'what,' is also found in Carinthian Slovene phrases adduced in Zdovc 1972 (109), reproduced in $(9 \mathrm{a}-\mathrm{c})$.

(9) a. Ko pa je?

What FOc be.PRs.3sg

'What is it?' / 'What's the matter?'

b. Ko pa bo?

What Foc be.FUT.3sg

'What's will it be?' / 'What's gonna happen?'

c. Ko pa sə rekli?

What FOC AUX.3PL say.PST.PTCP.PL

'What did they say'

These correlate to to Prekmurje Slovene, as illustrated in example (10), which appears in Mukič 2005: 143.

(10) $K a ̊ \quad g e ́ ?$

What be.PRS.3SG

'What is it?' / 'What's the matter?'

In contrast to the Carinthian dialect of Slovene (which has the compounded form characteristic of most of Slovene and Croatian Kajkavian ${ }^{\star} k a-j b>k$,ón $\sim$ qó i Zdovc 1972:55, 134), in Prekmurje Slovene (stressed) kä is the normal form for the pronoun 'what.' There is good reason to think that the non-compounded from is the identical form in both Carinthian and Prekmurje Slovene. As I have pointed out in Greenberg (2000:65), rounded ${ }^{\star} a$ was preserved longer in Carinthian and Pannonian dialects of Slovene, at least until the post jer-fall, as these two areas failed to merge strong jers with the reflex of ${ }^{\star} a$. Finally, returning to the aforementioned temptation to connect the Prekmurje dialect development to Balkan Slavic developments, it is enticing to see a connection between Prekmurje and Macedonian with the deka : $d a$ (roughly realis : irrealis), given the superficial 
resemblance of the forms and their function. As it turns out, however, deka is built from * $(k b) d e$ 'where' + a particle - $k a$ that is widespread as a suffixal extension in standard and dialectal Macedonian appearing with pronouns and adverbs of time, as well as the interrogative deka 'where' as in the example in (11), provided by Victor Friedman (p.c., see also Friedman 2015).
(11)

$\begin{array}{lll}\text { Deka ti } \quad e & \text { kukjata? } \\ \text { Where you.DAT } & \text { be.PRS.3SG } & \text { house.DEF } \\ \text { 'Where is your house?' } & \end{array}$

Regarding the subordinator $d a$, however, the Macedonian situation is indeed parallel to the development in Prekmurje in that it preserves the inherited Slavic irrealis semantics from Proto-Slavic.

\subsection{Slovene context}

In at least two respects, the Prekmurje dialect's strategies for clause-combining differ from standard Slovene. Crucially, the Prekmurje dialect is more conservative with regard to the means of subordinate clause formation than Standard Slovene; with regard to the South Slavic dialect continuum, it is more conservative with regard to the preservation of the infinitive (vs. its loss) (see also Friedman and Joseph 2019). First, the use of participles, especially the present active (-oč-/-eč-) and past active (-[v] $\bar{s}^{-}$) participles have remained longer in robust use in Prekmurje and eastern Slovene dialects, which lent this material to the standardization process of modern standard Slovene in the nineteenth century, in contrast to the central dialects around the capital, Ljubljana, where participial constructions as clause-forming elements had already gone out of use (Jesenšek 1998) (see also discussion in 2.3). Second, the Prekmurje dialect retains the contrast in form between the infinitive and supine in contradistinction to the colloquial language as spoken in the central areas of Slovenia (notably, the urban spoken language of Ljubljana). Thus, Prekmurje has püti 'drink-INF', pit 'drink-suP' while colloquial central (Upper Carniolan) Slovene has pitt (or with local variations in vowel reduction, e.g., pät, pët) 'drink-INF', pît 'drink-SUP', corresponding to orthographic piti, pit. The innovative central Slovene infinitive presents a puzzle, since both the reduction of short-stressed $-i$ - to $\partial$ and loss of the final $-i$ are attributable to the "modern vowel reduction," a process that began in the 16th century. However, the acute-stressed short vowel in the infinitive should have been preserved as short only if it were in the final syllable by the 15th century, implying that the loss of final -i preceded the lengthening of non-final acute-stressed syllables (see 
Greenberg 2000: 128, 147). This suggests that the central Slovene "short infinitive" arose (for morphological, rather than phonological, reasons) prior to the fifteenth century, which is to say that, pitch-accent contrasts between the infinitive and supine aside, the terminal shape of the two forms had become conflated to $-t$. This fact is interesting for at least two reasons: one, the loss of final $-i$ in the infinitive has been noted as the first stage of the loss of the infinitive in the Balkan Slavic languages (see Joseph 1983: 139 for details), placing the nascent process in central Slovene together with those of Balkan Slavic in such a way that it is evidently not a function of geographical diffusion, as well as placing Prekmurje outside of the innovative zone (note also that acute lengthening never took place there); and, two, the ongoing loss of the infinitive (and supine) is a precursor to the expansion of $d a$-clauses in Balkan Slavic languages. These facts suggest that the processes of change in the infinitive and supine forms may be structure-driven in South Slavic, e.g., the loss of final $-i$ in the infinitive does not result in conflation with the supine, where it survives, since the two are distinguished by word-prosody in Western Balkan Slavic, and at least not entirely a function of contact change. Further, they suggest by extension that the parallel development in subordinate-clause marking between Prekmurje and Balkan languages is not a common innovation but a parallel development, each motivated by local conditions.

\subsection{Slovene and BCMS context}

Though standard Slovene employs $d a$ as the default subordinating conjunction, $d a$ also has clause-marking functions that are relics of its earlier, richer semantics. At the beginning of a main clause, $d a$ marks optative constructions, often with an emotional color, such as urgency or threat, as illustrated in example (12).

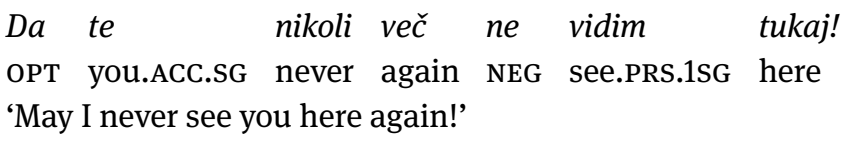

As in Slovene, main-clause-initial $d a$ in BCMS (Štokavian) can also be used to signal emotionally charged direct commands, as in example 13.

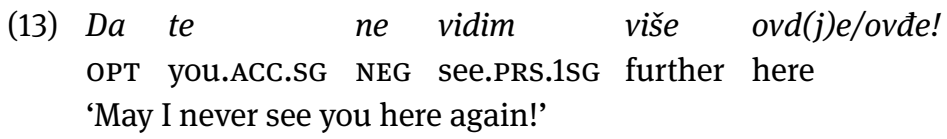


Optative usages in Štokavian are fossilized in lexicalized wishes and curses, derived from phrases, such as dabogda 'I hope, let's hope' ( $<$ da bog da 'May God give'), or dabo(g)me 'of course' (< da bog me [verb.TR] 'may God [verb.TR] me').

\subsection{Peculiarities of $d a$ in $\mathrm{BCMS}$}

As mentioned above, the Kajkavian dialect today has da-complementation as in the rest of BCMS and there has been no mention in the literature of $k a$ complementation. This is worth noting to avoid the tacit assumption that Štokavian-based BCMS standards stand in for the non-Štokavian varieties of Croatian. In this sense, the Prekmurje contrast can be viewed as a local development on the notion that what does not go for central Slovene can sometimes be found in Kajkavian. Though Kajkavian $d a$-complementation by and large agrees with Štokavian, in one subtle way it differs from it in that $d a$ is also used to mark reported speech, as illustrated in example (14) (Lončarić 1996: 131).

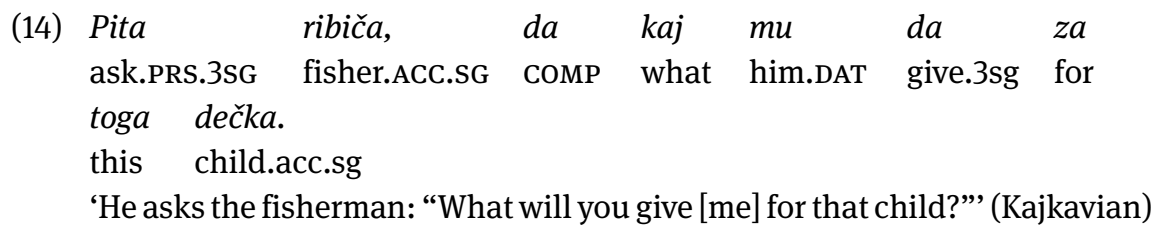

Colloquial Štokavian permits this usage, as well, though $d a$ is inserted (where $\emptyset$ would be neutral) to emphasize reported speech (Mate Kapović, p.c.), as in example (15).

(15) Kad mu priđe milicajac $i$ pita ga

When him.DAT come.3sg cop and ask.3sg him.ACc.sG

da što to čita ...

COMP what this read.3sG

'When the cop comes and asks him "What are you reading. ..' (Štokavian)

(internet forum http://hpgf.org/viewtopic.php?style=10\&f=8\&t=1738

accessed 26 October 2019).

In this respect, both in Kajkavian and Štokavian $d a$ functions as a marker of reported speech, apparently obligatorily in the former and optionally in the latter. The matter deserves further investigation, given that these comments are based on limited data, especially regarding Kajkavian. 


\subsection{Idiosyncrasy of the Prekmurje evidence}

Another discrepancy in this regard between the Prekmurje dialect and the Balkan Slavic languages is in the material available for examining the phenomenon in question. The time horizon for attestation of the Prekmurje dialect begins in the first quarter of the eighteenth century with translations of the New Testament, devotional texts, a relatively small number of ephemeral texts for local consumption (calendars, newspapers) (see Jesenšek 2005), a Hungarian-language grammar of a proposal for standard Prekmurje Slovene (Pavel 1942, 2013), dialect texts (Pavel 1917, 1918), and the occasional attempt to revive the Prekmurje literary language (e.g., Ftičar 2004, 2006). The corpus of canonical Prekmurje texts, from which the dictionary of Old Literary Prekmurian (Novak 2006) is sourced, dates from 1715 to 1886 (Novak 2006: viiiix). Furthermore, the $d a: k a$ contrast in the generation born after the Second World War has apparently been lost in favor of the complete generalization of $k a$ as a general marker of complementation/subordination. This means that understanding the contrast requires triangulation from the heterogeneous attestations rather than working with the testimony and internal knowledge of native speakers.

\section{The distribution of $\mathrm{da}, \mathrm{ka}$ in the Prekmurje dialect}

\subsection{The Prekmurje situation up to 1942}

In this section the distribution of the subordinating markers are described from extant materials up to the composition of Pavel's 1942 grammar, after which the project to standardize the Prekmurje dialect was abandoned.

In transcripts of oral narrative (Pavel 1917, 1918), ${ }^{2}$ we can observe when these two principles are set in tension with each other. Thus, in example (16), where the narrative frame is about wish-making, the same verb of speaking is used, but the DC contains a wish that is intended to be fulfilled.

2 Examples from Pavel 1917 and 1918, once so designated as from this source, are noted by page numbers alone, which do not overlap, i.e., $1917=$ pp. $161-187,1918=263-282$. Some of the phonetic details of the transcription are simplified in the paper, as they are irrelevant to the topic. 
(16) D’ầs san právla, da bi d'äs näjrä̀j ń nuvoga I AUX said COMP COND I most.of.all their ìnaša mèila. servant have

'I said that I would like most of all to have your-[extra-deferential] servant.' (Pavel 1918: 265)

Though the same verb praviti 'say' is used in the CTP of both examples (1) and (16), the illocutionary force differs in that in (1) the speaker expresses commitment to the proposition in the DC, while in (16) the DC contains a proposition that may or may not be realized and is independent of the volition of the speaker. In example (17) the speaker is the impersonal 'they' and the verb in the CTP asserts that what follows in the DC is a truth valid for all time, again favoring $k a$.

(17)

$\begin{array}{llllll}\text { Právijo, } & \boldsymbol{k} a & \text { so } & \text { bräzglafci } & \text { düšä } & \text { têstä } \\ \text { they.say } & \text { comp } & \text { are } & \text { headless.ghosts } & \text { souls } & \text { those } \\ \text { präminôčä } & \text { dicé, } & \text { štära } & \text { bräzi } & \text { kr̀sta } & \text { märjéjo. } \\ \text { passing.away } & \text { children } & \text { which } & \text { without } & \text { baptism } & \text { they.die }\end{array}$

'They say that the headless ghosts are the souls of passed-away children who die without baptism.'

(Kühar 1911: 57)

\subsection{Analysis of distribution of $k a: d a$}

Verbs of perception in CTP consistently trigger $k a$-complementation in the DC, as in examples (18-20). This comports with the notion that perception is an affirmation of something observed and, accordingly, knowledge acquired in the real world, rather than a potential action or event.

(18) Eden pa 'znyih vidoucsi, ka je ozdravo; povrno One and from.them seeing comp AUX healed turned fze je zvelikim glászom dicsécsi Bogà.

REF AUX with.great voice glorifying God

'One of them, seeing that he was healed, came back, praising God in a loud voice'

(Küzmič 1771: 229, Luke 17:15) 
(19) Vido je, $\boldsymbol{k a}$ je žalosten.

He.saw Aux comp is sad

'He saw that he is sad.'

(Novak 2006: Jožef Bagary 1886, s.v. viditi)

(20) Zaglä̀dno jä, $\quad$ ka nikša škatla dòj po vòudi plàva. He.noticed AUX comp some box below on water floats 'He saw that some box was floating on the water.'

(Pavel 1918: 269)

Pavel states in his prescriptive grammar that $d a$ is preferred after verbs expressing emotions, as illustrated in $(21,22)$, though other clause linkers may also occur in the DC responding to the question zakaj 'why': ár 'because', jer 'because' e.g., Szilje je lepô, ár szmo dobro letino meli 'The grain is good, because we had a good harvest' (§ 444).

(21) Trno me veszelí, da(ka) szi zse pá zdrav. very me pleases comp AUX-2SG already again healthy 'I am very pleased that you are healthy once again' (Pavel 1942 § 444)

Thus the expression of an emotional state such as biti žalosten 'be sad' in the CTP tends to trigger the appearance of $d a$, as noted descriptively in a transcribed folktale (22)

$\begin{array}{lllllll}\text { (22) Kà } & \text { bi } & \text { näbi } & \text { büu } & \text { žàlostän } & \text {-právi } & \text { srmák- } \\ \text { How } & \text { COND } & \text { NEG-COND } & \text { was } & \text { sad } & \text { says } & \text { wretch } \\ \boldsymbol{d a} & \text { san } & \text { tòi } & \text { dèitäcä } & \text { òudo! } & & \\ \text { COMP } & \text { AUX-1SG } & \text { this } & \text { baby } & \text { sold } & & \end{array}$

“"How would I not be sad,” said the wretch, "that I have sold this baby!” (Pavel 1917: 175)

\subsubsection{Combination with conditional bi and purpose clauses}

Pavel asserts that $d a$ also marks potential, unrealized states or events, noting in Pavel 1942 that DCs of purpose require da bi (i.e., with the addition of the conditional-optative marker) and cannot be marked with $k a$ or $k a b i$, implying that speakers are likely to produce the latter. The prohibition on $k a b i$ is perhaps Pavel's normativist intervention, as such constructions abound in the historical texts, e.g., 
(23) ki je na pouli;

whichever be.3SG on field.LOc.sG

naj fze ne povrnè konim;

OPT.COMP REFL NEG return.3SG to them.DAT

ftera je za fzebom niháo,

which.N.ACC.PL be.3sg after self.INS leave.PST.PTCP.M.SG

ka bi vzeo gvant fzvoj

COMP COND take. PST.PTCP.M.SG cloak.M.ACC.SG one's.own.M.ACC.sg.

'whoever is in the field, may he not return to those things that he has left

behind, so that he may take his cloak'

(Küzmič 1771: 144, translating Mark 13:16)

Küzmič 1771 has 270 instances of $d a b i$ against 156 instances of $k a$ bi, indicating that $k a$ had become a possibility alongside $d a$ in purpose clauses (alongside naj, as evidenced in the example 23) even in the eighteenth century. By inference we may surmise that the addition of bi sufficiently weakens the epistemic force of $k a$ : da so that either form is acceptable in this combination. Pavel also points out that purpose clauses may be substituted with the supine, as in 24.

$\begin{array}{llll}\text { (24) Bozsi szin je } & \text { priso } & \text { szvêt odrêsit } \\ \text { God's.Nom.sg.m son } & \text { AUX.3SG come.PST.PTCP.M.SG } & \text { world save.suP } \\ \text { 'God's son came to save the world' } & \end{array}$

(Pavel § 445)

As in standard Slovene, the supine occurs only in a clause following a verb of motion.

\subsubsection{Future readings in the CTP}

Similarly, future tense propositions are read as potential, favoring $\mathrm{da}$. In example (25) the text is immediately preceded by a statement proposing a soon-to-be, but as yet unrealized, world in which the Prekmurje written language will be fully developed and put into use for the production of literature (Pride csasz, i ne je dalecs, gda bomo vu nasen maternom jeziki csteli dobra, csedna, postena, düsi $i$ teli hasznovita dela 'There will come a time, and not long from now, when we will be able to read good, beautiful, honest, works, useful for soul and body alike, in our mother tongue'.) 
(25) Niscse nemre prebraniti da vszaki bode

nobody cannot prohibit comP each FUT-3SG

csteo kaj dobroga vu szvojem jeziki...

read something good in own language

'Nobody can prevent that each will be able to read something good in one's own language...'

(Kalendar 1915, cited in Jesenšek 2005: 90)

Scanning the whole of the 1771 Gospel, no examples of DC with $k a+$ future were found, though examples, as in (26) of $d a$ + future are attested.

(26)

$\begin{array}{lllll}\text { hodta } & z a & \text { menom } & i \quad v c s i n i m & \text { váj; } \\ \text { you.two.walk } & \text { after } & \text { me } & \text { and I.shall.make-PFV you.two } \\ \boldsymbol{d a} & \text { bodeta } & \text { lüdi } & \text { ribicsa } & \\ \text { that } & \text { you.shall.be } & \text { of.people } & \text { two.fishermen } & \\ \text { 'follow me and I shall make you fishers among men.' } \\ \text { (Küzmič 1771: 104; Mark 1:17) }\end{array}$

\subsection{The Prekmurje situation from the second half of the 20th century}

\subsubsection{Reduction and elimination of $d a$}

As mentioned earlier, the contrast between $d a$ and $k a$ has apparently been lost in the generations that came of age after the Second World War, an observation from my own fieldnotes as well as the confirmation of a native-speaker researcher at ZRC SAZU, Mojca Horvat (p.c.). ${ }^{3}$ This would seem additionally confirmed by the absence of any examples of $d a$-complements in the recent Porabje dialect dictionary by Mukič (2005), which reflects the variety of the Prekmurje dialect spoken on the Hungarian side of the border and, as such, the variety that would have had the fewest opportunities for influence from standard Slovene. Examples (27-29) are provided with the equivalent standard Slovene and standard Hungarian translations, in this order, as they are presented in the dictionary. Example (27) represents the control case, since its obvious reading is factual, where the

3 My fieldwork, conducted in the late 1980s, focused on phonology and accentual paradigms in inflected words, so any notes that included information about clause combining would have been collected unsystematically. 
CTP presents a circumstance that is asserted to be observable in the real world. Accordingly, $k a$ would be the expected conjunction and so it is.

(27) PSn Kå tåu za déla, ka tåk prklinjaš? what this for matters CoMP so you.cuss

StSn Kaj se to pravi da tako kolneš what REFL this says COMP to you.cuss

'What's up with that, that you are cussing so much?' (Hung. Micsoda dolog, így káromkodni?)

(Mukič 2005, s.v. délo)

Example (28 a, b) presents a purpose clause in the DC, which would have historically favored $d a b i$ in Prekmurje Slovene, but here $k a$ bi is instead attested.
(28) a. PSn Záto je príšo, ka bi dúg võpláčo. for.that AUX-3SG came COMP COND debt paid
b. StSn Zato je prišel, dabi poravnal svoj dolg. for.that AUX-3SG came COMP COND paid own debt 'He came in order to pay his debt' (Hung. Azért jött, hogy rendezze az adósságát)
(Mukič 2005, s.v. $k a^{1}$ )

Example (29 a, b) presents both a future and (as yet) unrealized circumstance in the DC, though the CTP frames the assertion as an epistemic commitment to a future world. As such, the choice of the conjunction could have gone either way, but, again, only $k a$ is attested. A factual and causal DC also takes $k a$, as in (30 a, b).
(29) a. PSn Nakåno je ka nede vě píu. decided AUX-3SG COMP NEG-FUT-3SG more drink
b. StSn Odločil se je, $\mathrm{da}$ ne bo decided REFL AUX-3SG COMP NEG FUT 3SG več pil. more drink

'He decided that he would no longer drink.' (Hung. Megfogadta, hogy nem iszik)

(Mukič 2005, s.v. nakåniti) 


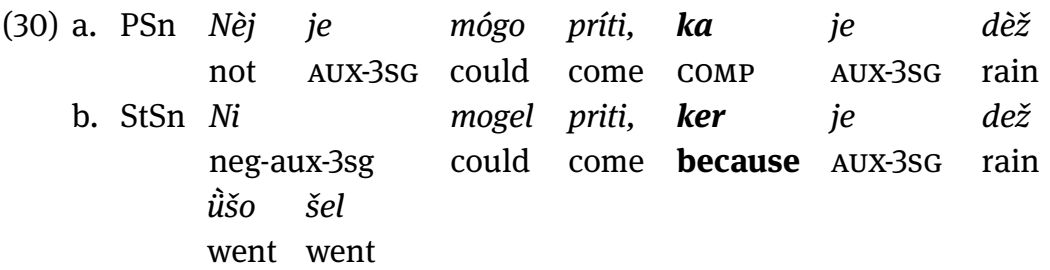

'He couldn't come because it was raining' (Hung. Nem tudott eljönni, mert esett)

(Mukič 2005, s.v. $k a^{2}$ )

Perhaps the most compelling example is (31 a, b), in which the main clause frames the event as future and the subordinate clause presents a potential, but ultimately unrealizable action, both of which would have historically favored $d a$. Here, again, $k a$ is attested.

$\begin{array}{lllll}\text { a. PSn } & \text { Tåk } & \text { te } & \text { v rít bŕsnen, } \\ & \text { so } & \text { you } & \text { in butt } & \text { I.shall.kick } \\ & \text { ka } & \text { boš } & \text { lèto } & \text { k trístau vragón! } \\ & \text { COMP } & \text { you.shall } & \text { fly } & \text { to 300 devils } \\ \text { b. StSn } & \text { Tako } & \text { te } & \text { bom } & \text { sunil v rit, } \\ & \text { so } & \text { you } & \text { I.shall } & \text { kick in butt } \\ & \text { da } & \text { boš } & \text { videl } & \text { tristo hudičev } \\ & \text { comp } & \text { you.shall } & \text { see } & \text { 300 devils }\end{array}$

'I'm gonna kick you so hard in the butt that you are going to fly to the moon!' (Hung. Úgy fenékben billentelek, hogy attól koldulsz)

(Mukič 2005, s.v. rít)

Finally, there is evidence from an epistolary memoir by the Prekmurje native journalist Jože Ftičar (1930-2017), who was a sophisticated writer of standard Slovene in his career, was trained as a dialectologist, but in the memoir wrote in a consistent rendering of the dialect that in general terms conforms to the norm outlined by Pavel (1942, 2013), though using the gajica orthography as in standard Slovene (Ftičar 2004, 2006). Ftičar's native village was Gomilica in southeastern Prekmurje, which in terms of the internal divisions of the dialect is furthest from that spoken in Porabje (north) though closer to Pavel's native village of Cankova (west) (see Greenberg 1993 for details). Nevertheless, after scanning some 20 pages of text, I found that the distribution of $k a$ : $d a$ is clear-cut, where $k a$ is the default and da may occur only in combination with the conditional marker bi.

In example (32) the factual-signaling $k a$ is expected and attested, as the CTP contains a verb of perception and the DC contains an observed event in the real world. 
(32) Vidin, ka vaj víno podéžgalo... see.1sg comp you.Du wine fired.up.PST.PTCP.N.SG 'I see that the wine has fired the two of you up. ..' (Ftičar 2006:16)

Examples (33) and (34), in which the DC is a purpose clause, would have earlier favored $d a$, but instead we find $k a$. Example (34) would be the stronger case for $d a$, given that the $\mathrm{DC}$ is hypothetical, while example (33) represents a potential action that is also understood to have been realized. Only in example (35) is da triggered in a DC with a hypothetical circumstance that is entirely in an imaginary world, suggesting that the use of $d a$ has now, at least in Ftičar's idiolect, restricted to non-real-world hypothetical actions or circumstances.

(33) ...je stópo žnjin na škêgen, ka bi bole čüu... AUX-3sG stepped with.him onto barn COMP COND better heard '. . he stepped with him into the barn in order to better hear. . .'

(Ftičar 2006: 17)

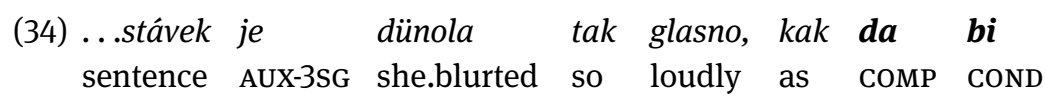
ga strèskali $\quad$... plivánuš Sàkovič sprèdgance

it they.thundered Father Sàkovič from pulpit

'. . . she blurted out the sentence so loudly that it was as if Father Sakovič had thundered it from the pulpit ...'

(Ftičar 2006: 22)

Note also in (35) that $k a(d a) b i$ have not fused, as they still admit intervening clitics.

$\begin{array}{llll}\text { (35) ...se bránijo } & \text { dicé, } & \text { ka se ne bi } & \text { zêmla prêveč } \\ \text { REFL they.defend } & \text { children } \\ \text { cazfrčkala... } & & & \\ \text { divided... } & & & \\ \text { comp REFL NEG COND land } & \end{array}$ '. . .they oppose the children, so that the land wouldn't be divided up too much ...'

(Ftičar 2006: 20) 


\section{Discussion and conclusion}

Above we have described the rise and fall of an opposition between two complementizers/subordinators $d a: k a$ in Prekmurje Slovene, which bears a resemblance to a parallel phenomenon in Balkan Slavic and other Balkan Sprachbund languages. The Prekmurje development is, however, independent of the Balkan one, as the generalization of $d a$ as a general marker of subordination had reached the northern limit of the South Slavic territory by the 11th century, as evidenced by the Freising Folia (ex. 4). The general meaning of $k a$ as marker of 'real, factual' propositions and $d a$ as 'possible, potential' ones was recognized by native grammarians in the early part of the 20th century (Kühar, Pavel, see section 2.0). Pavel noted that the distribution of the markers was of a probabilistic nature, where the expected marker occurs more frequently in the contexts noted in examples $(1,2)$.

With regard to the internal, notional reticulation of reality status in Prekmurje Slovene as signaled by $k a: d a$, we may draw some inferences from the data examined. Assertion of fact and commitment to the truth value of the proposition in the subordinate clause seems to be the fundamental notion anchoring the use of the $k a$-subordinator, as indicated by the consistent use of $k a$ with CTPs containing verbs of perception and DCs containing a proposition presented as witnessed and having taken place in the world, as in examples 18-20. In a parallel fashion verba dicendi are treated the same (example 17). Standing outside of the epistemic modality noted by Chung and Timberlake (section 1.1), CTPs expressing a state of emotion trigger $d a$ in the DC (examples 21, 22) and override the factual-signaling function of $k a$. What is at stake in Prekmurje Slovene is that there are at least two distinctions operating with the $k a$ : da contrast, one opposing real vs. irreal and another opposing description vs. emotion/evaluation. .

CTP future propositions require $d a$ and, at least through the 18th century, $k a$ appears to have been excluded from future-oriented DCs (examples 25, 26). DCs with the combination of $d a+b i$ (conditional marker), with a statistical prevalence of $d a$ bi over ka bi, are noted in 18th-century texts (section 3.13). Furthermore, in the end period when the subordinator opposition has nearly collapsed in favor of the generalization of $k a, d a b i$ persists sporadically in 20th c. attestations, as in example $(34)$, as contrasted with $k a$ bi uses $(33,35)$ from the same author. To summarize, up through the first half of the 20th century, da clauses in Prekmurje Slovene were favored in the context of epistemic modality where either futurity or conditionality are expressed; an emotional state of the speaker overrides the notion of epistemic modality. Those that hew to or are asserted to be identical to or close to the actual world condition $k a$-clauses. In the second half of the 20th century the opposition collapses in favor of $k a$, removing the marked member of the opposition. 
It is tempting to speculate about additional, non-structural causation for the collapse of the opposition in favor of $k a$ as the general subordinator. In part it is clear, both from the attestations and from the optionality indicated by Pavel's Sprachgefühl, as articulated in his grammar, that the notional motivations underlying the forms had been labile as early as the earliest texts in the first part of the 18th c. and that $d a$ was the marked, $k a$ the unmarked form. In this sense the erosion of the system in favor of the unmarked form is unsurprising. However, when regarded in a sociolinguistic perspective, taking into consideration the connections between Prekmurje Slovene both with central Slovene and the Kajkavian dialect, which both pattern with (Štokavian-based) BCMS in generalizing $d a$, it raises the question of why Prekmurje remained resistant to the overall western South Slavic tendency. Here there may be an additional motivation that speaks to a preference for linguistic style, that is, linguistic identity, which has served to sharpen the contrast between the dialect and its neighbors $\mathrm{cf}$. the sentiment expressed in the example in example 25. As this issue had not been addressed in the literature and we now lack the generation of speakers who could verify this potential motivation, the matter must remain speculative.

To summarize the developments described in this paper we can sketch the following processes as presented in Table 1.

Table 1: Proposed chronology of developments.

\begin{tabular}{ll}
\hline Balto-Slavic to Slavic (up to ca. 1000 AD) & $\begin{array}{l}\text { Participial subordinating construction yield to } \\
\text { comp-headed subordinated clauses. }\end{array}$ \\
\hline by 1000 AD & modal comP da prevails in South Slavic \\
\hline 12th c. AD on & $\begin{array}{l}\text { Infinitive loss in eastern South Slavic, } \\
\text { spreading gradually westward. }\end{array}$ \\
\hline by 1500 & $\begin{array}{l}\text { Short infinitive in central and southern Slovene } \\
\text { dialect reflects nascent infinitive loss, which } \\
\text { north-eastern Slovene (Prekmurje) remains } \\
\text { conservative. }\end{array}$ \\
\hline by 18th c. & $\begin{array}{l}\text { Prekmurje develops factual ka comP, competing } \\
\text { with da comP. }\end{array}$ \\
\hline 2nd half of 20th c. & $\begin{array}{l}\text { All but relic usage of } d a \text { bith cond bi is replaced } \\
\text { by ka comp in Prekmurje. }\end{array}$ \\
\hline
\end{tabular}




\section{Abbreviations}

$\begin{array}{ll}\text { BCMS } & \text { Bosnian, Croatian, Montenegrin, Serbian } \\ \text { CTP } & \text { complement-taking predicate } \\ \text { DC } & \text { dependent clause } \\ \text { FF } & \text { Freising Folia (Bernik, Faganel, et al. 1992) } \\ \text { Germ } & \text { German } \\ \text { Hung } & \text { Hungarian } \\ \text { PSn } & \text { Prekmurje Slovene } \\ \text { StSn } & \text { Standard Slovene }\end{array}$

\section{References}

Ammann, Andreas and Johan van der Auwera. 2004. Complementizer-Headed Main Clauses for Volitional Moods in the Languages of South-Eastern Europe. In Olga Mišeska Tomić (ed.), Balkan Syntax and Semantics, 293-314. Amsterdam: Benjamins.

Ambrazas, Vytautas. 1990. Sravnitel'nyj sintaksis pričastij baltijskix jazykov [Comparative syntax of participles in the Baltic languages]. Vilnius: Mokslas.

Andersen, Henning. 1970. The Dative of Subordination in Baltic and Slavic. In Thomas F. Magner \& William R. Schmalstieg (eds.), Baltic Linguistics, 1-9. University Park \& London: The Pennsylvania State University Press.

Bernik, France \& Jože Faganel et al. 1992. Brižinski spomeniki [The Freising Folia]. Ljubljana: Slovenska knjiga.

Bulgarian National Corpus http://dcl.bas.bg/bulnc/

Bybee, Joan. 1998. 'Irrealis' as a Grammatical Category. Anthropological Linguistics 40 (2). 257-271.

Chung, Sandra and Alan Timberlake. 1985. Tense, Aspect, and Mood. In Timothy Shopen (ed.), Language Typology and Syntactic Description, vol. 3: Grammatical Categories and the Lexicon, 202-258. Cambridge: Cambridge University Press.

Friedman, Victor A. 2015. Sometimes a Cigar is Just a Cigar: Bulgarian and Macedonian QUIPs and Their Relatives. In Ljudmila Popović, Dojčil Vojvodić \& Motoki Nomachi (eds.), U prostoru lingvističke slavistike / Inside the Space of Slavic Linguistics, 768-776. Belgrade: University of Belgrade.

Friedman, Victor A. \& Brian D. Joseph. 2019. The Importance of Slovene for Understanding Balkanisms. In Stephen M. Dickey \& Mark Richard Lauersdorf (eds.), V zeleni drželi zeleni breg. Studies in Honor of Marc L. Greenberg, 79-89. Bloomington: Slavica Publishers.

Ftičar, Jože. 2004, 2006. Za nápršnjek vedríne [For a bit of optimism] I., II. Murska sobota: Stopinje

Greenberg, Marc L. 1993. Glasoslovni opis treh prekmurskih govorov in komentar k zgodovinskemu glasoslovju in oblikoglasju prekmurskega narečja [Phonological description of three Prekmurje village dialect systems and commentary on the historical phonology and morphology of the Prekmurje dialect]. Slavistična revija [The journal of Slavistics] 41 (4). 465-487. 
Greenberg, Marc L. 1999. Multiple Causation in the Spread and Reversal of a Sound Change: Rhotacism in South Slavic. Slovenski jezik / Slovene Linguistic Studies 2. 63-76.

Greenberg, Marc L. 2000. A Historical Phonology of the Slovene Languages. Heidelberg: Winter.

Greenberg, Marc L. 2011. A Balkanism in Central Europe? Realis vs. Irrealis in Subordinate Clauses in Prekmurje Slovene. In Zbyněk Holub \& Roman Sukač (eds.), Dialektologie $a$ geolingvistika v současné střední Evropě, 8-18. Opava: Slezská univerzita v Opavě.

Greenberg, Marc L. 2013. Prekmurščina med slovanskimi jeziki [The language of Prekmurje among the Slavic languages]. In Avgust Pavel: Prekmurska slovenska slovnica. Vend nyelvtan [Prekmurje Slovene Grammar]. Zbirka Zora, v. 100. Marija Bajzek Lukač (trans.), Marko Jesenšek (ed.), 401-412. Bielsko-Biała, Budapest, Kansas, Maribor \& Prague: Zora.

Greenberg, Marc L. 2019. Subordinating Conjunctions in the Slovene Trans-Mura River (Prekmurje) dialect and their Balkan parallels. In Donald L. Dyer, Brian D. Joseph, \& Mary Allen Johnson (eds.), The Current State of Balkan Linguistics: Celebrating Twenty Years of the Kenneth Naylor Lectures [Special issue]. Balkanistica 32 (1). 209-222.

Grickat, Irena. 1975. Studije iz istorije srpskohrvatskog jezika [Studies in the history of Serbo-Croatian]. Belgrade: Narodna biblioteka SR Srbije.

Ivić, Pavle. 1958. Die serbokroatischen Dialekte. Ihre Struktur und Entwicklung. 1. Band: Allgemeines und die štokavische Dialektgruppe. The Hague: Mouton \& Co.

Jesenšek, Marko. 1998. Deležniki in deležja na -č in -ši (= Zbirka Zora 5) [Participles and gerunds in $-\check{c}$ and $-s ̌ i=$ (Zora series)]. Maribor: Slavistično društvo Maribor.

Jesenšek, Marko. 2005. The Slovene Language in the Alpine and Pannonian Language Area. Cracow: Universitas.

Joseph, Brian. 1983. The Synchrony and Diachrony of the Balkan Infinitive. A Study in Area, General and Historical Linguistics. Cambridge: Cambridge University Press.

Kopečný, František, Václav Polák \& Vladimír Šaur. 1980. Etymologický slovník slovanských jazyků: Slova gramatická a zájmena [Etymological dictionary of the Slavic languages: grammatical words and pronouns], vol. 2. Prague: Academia.

Krajčovič, Rudolf. 1974. Slovenčina a slovanské jazyky I. Praslovanská genéza slovenčiny [Slovak and Slavic languages I. The Proto-Slavic genesis of Slovak]. Bratislava: SPN.

Kühar, Števan. 1911. Národno blágo vogr̀skij Slovầncof [The cultural goods of the Hungarian Slovenes]. Časopis za zgodovino in narodopisje [Journal of history and ethnography] 8. 47-76.

Küzmič, Štefan (trans.). 1771. Nouvi zákon ali Testamentom goszpodna nasega Jezusa Krisztusa [The New Testament of our Lord Jesus Christ]. Halle.

Leafgren, John. No date. A Concise Bulgarian Grammar. SEELRC Grammars. http://www.seelrc. org:8080/grammar/mainframe.jsp?nLanguageID=9

Lončarić, Mijo. 1996. Kajkavsko narječje [The Kajkavian dialect]. Zagreb: Školska knjiga.

Lunt, Horace G. 2001. Old Church Slavonic Grammar. 7th edition. Berlin \&New York: Mouton de Gruyter.

Mukič, Francek. 2005. Porabsko-knižnoslovensko-madžarski slovar [Porabje-standard SloveneHungarian dictionary]. Szombathély: Zveza Slovencev na Madžarskem.

Novak, Vilko. 2006. Slovar stare knjižne prekmurščine [Dictionary of the old Prekmurje literary language]. Ljubljana: ZRC SAZU, Institut za slovenski jezik Frana Ramovša. 
Noonan, Michael. 1985. Complementation. In Timothy Shopen (ed.), Language Typology and Syntactic Description, vol. 2: Complex Constructions, 42-140. Cambridge: Cambridge University Press.

Nordström, Jackie. 2010. Modality and Subordinators. Amsterdam: Benjamins.

Pavel, Avgust (Pável Ágost). 1917. Vend szöveggyüjtemény s az eddigi gyüjtések története [A collection of dialect texts in the Prekmurje language with the history of their collection to date]. Nyelvtudomány [Philology] 6 (3). 161-187.

Pavel, Avgust (Pável Ágost). 1918. Vend szöveggyüjtemény s az eddigi gyüjtések története (folytatás és vége) [A collection of dialect texts in the Prekmurje language with the history of their collection to date (continuation and conclusion)]. Nyelvtudomány [Philology] 6 (4). 263-282.

Pavel 1942 = Greenberg, Marc L. (editor and translator). 2020. Prekmurje Slovene Grammar. Avgust Pavel's Vend nyelvtan (1942). Leiden: Brill.

Pavel, Avgust. 2013. Prekmurska slovenska slovnica. Vend nyelvtan [Prekmurje Slovene grammar. Wendish/Prekmurje Slovene grammar]. Zora, v. 100. Bielsko-Biała, Budapest, Kansas, Maribor \& Prague: Zora

Perseus 4.0 = Gregory R. Crane (editor). Perseus Digital Library 4.0. http://www.perseus.tufts.edu/hopper

Ramovš, Fran. 1952. Morfologija slovenskega jezika [Morphology of the Slovene language]. Ljubljana: DZS.

Schallert, Joseph and Marc L. Greenberg. 2007. The Prehistory and Areal Distribution of Slavic *gblčĕti ‘Speak’. Slovenski jezik / Slovene Linguistic Studies 6. 9-76. http://dx.doi. org/10.17161/SLS.1808.4398

Sihler, Andrew L. 1995. New Comparative Grammar of Greek and Latin. New York: Oxford University Press.

Snoj, Marko. 1997. Kaj je kaj? [What is kaj 'what’?] In Jože Toporišič (ed.), Škrabčeva misel [Škrabec's thought] II: 187-192. Nova Gorica: Frančiškanski samostan Kostanjevica.

Snoj, Marko. 2009. Slovenski etimološki slovar [Slovene etymological dictionary]. 3rd edition. Ljubljana: ZRC SAZU. Online edition (2015): http://www.fran.si/193/marko-snojslovenski-etimoloski-slovar

Vaillant, André. 1977. Grammaire comparée des langues slaves, tome V: la syntaxe. Paris: Klincksieck.

Večerka, Radoslav. 2006. Staroslověnština v kontekstu slovanských jazyků [Old Church Slavic in the context of the Slavic languages]. Olomouc \& Prague: Euroslavica.

Zdovc, Pavel. 1972. Die Mundart des südöstlichen Jauntales in Kärnten: Lautlehre und Akzent der Mundart der "Poljanci". Wien: Böhlau. 
Björn Wiemer, Barbara Sonnenhauser (Eds.)

Clausal Complementation in South Slavic 


\section{Trends in Linguistics Studies and Monographs}

\section{Editors}

Chiara Gianollo

Daniël Van Olmen

\section{Editorial Board}

Walter Bisang

Tine Breban

Volker Gast

Hans Henrich Hock

Karen Lahousse

Natalia Levshina

Caterina Mauri

Heiko Narrog

Salvador Pons

Niina Ning Zhang

Amir Zeldes

Editor responsible for this volume Daniël Van Olmen

\section{Volume 361}




\section{Clausal \\ Complementation in South Slavic}

Edited by

Björn Wiemer, Barbara Sonnenhauser

DE GRUYTER

MOUTON 
ISBN 978-3-11-072572-8

e-ISBN (PDF) 978-3-11-072585-8

e-ISBN (EPUB) 978-3-11-072593-3

Library of Congress Control Number: 2021941369

Bibliographic information published by the Deutsche Nationalbibliothek

The Deutsche Nationalbibliothek lists this publication in the Deutsche Nationalbibliografie; detailed bibliographic data are available on the Internet at http://dnb.dnb.de.

(c) 2022 Walter de Gruyter GmbH, Berlin/Boston Typesetting: Integra Software Services Pvt. Ltd.

Printing and binding: CPI books $\mathrm{GmbH}$, Leck

www.degruyter.com 


\section{Preface}

This volume presents a collection of articles that share a focus on South Slavic languages and clausal complementation. They offer insights on this topic from various perspectives, taking up issues relevant not only for specialists of (South) Slavic languages, but also for the broader linguistic community interested in clause combining, areal linguistics, language contact, diachronic syntax and/or corpus linguistics. In their entirety, the studies assembled here cover the entire linguistic geography of South Slavic, including exclave varieties in Italy as well as contact with non-Slavic languages such as Albanian and Hungarian.

The volume arose from the workshop "Variation in space and time: clausal complementation in South Slavic," which was funded by the Swiss National Science Foundation and organized by the editors on March 17-19, 2016, at the University of Zurich. Most of the contributors to this volume were also participants in that workshop. We thank every author for their continued motivation to contribute to this joint endeavor, which, as we hope, will help establish directions for the study of clause combining, in particular of clausal complementation, in Slavic languages in a modern framework. We are also obliged to an anonymous reviewer who provided thoroughgoing and valuable comments on every article and to Giulia Morra for her assistance in creating the index. Moreover, we thank the publishing house De Gruyter and, in particular, the editors in charge of the TiLSM series for taking our volume on board.

Björn Wiemer \& Barbara Sonnenhauser (Mainz / Zurich), April 2021 



\section{Contents}

Preface $-V$

Chapter I: Introduction

Barbara Sonnenhauser and Björn Wiemer

Clausal complementation in South Slavic: Introduction -3

Chapter II: Complementation structures

Björn Wiemer

A general template of clausal complementation and its application to South Slavic: theoretical premises, typological background, empirical issues -29

Alexander Letuchiy

Clausal complements of certain nominalizations in Bulgarian: Relevant parameters -160

Iliyana Krapova

Complementizers and particles inside and outside of the left periphery: The case of Bulgarian revisited — 211

Liljana Mitkovska and Eleni Bužarovska

Clausal complementation of visual perception verbs in Balkan Slavic $-\mathbf{2 7 0}$

Chapter III: Complementation in space

Marc L. Greenberg

Antemurale innovationis: Clausal complementation in the Slovene Mura River (Prekmurje) dialect and its Balkan parallels — 317

Walter Breu

Complementisers in language contact. The influence of Italian che on South Slavic and Albanian in Molise and beyond - 342

Chapter IV: Complementation in time

Hanne Martine Eckhoff

The history of Slavonic clausal complementation: A corpus view - 387 
VIII - Contents

Jasmina Grković-Major

The development of emotion predicate complements in Serbian -415

Barbara Sonnenhauser

Slovene naj: An (emerging) clausal complementiser? - 442

Author Bio Notes -477

Language index -481

Subject index -483 